\title{
The effect of the biopreparation product "Tamir" on cattle health and productivity
}

\author{
M.R. Kudrin, A.L. Shklyaev*, E.S. Klimova, G.V. Azimova, and S.P. Bass \\ FSBEI HE Izhevsk SACA, Izhevsk, Russia
}

\begin{abstract}
The article presents materials on the results of the study of the effect of the Tamir biopreparation on the growth indicators of repair heifers, the subsequent dairy productivity of cows and animal health as a result of the use of the biopreparation Tamir with a loose technology of keeping cattle on a deep litter. The work analyzed the technology of maintenance of repair heifers and cows, studied the indicators of live weight and average daily increments of repair heifers in different growing periods, studied the composition and method of preparation of the biopreparation "Tamir", the technology of biopreparation application for processing organic manure, analyzed the indicators of disposal of repair young animals and cows dairy productivity of first-calf cows for 100 days of lactation and by age categories for two years before and three years after the use of the biopreparation, studied the results of laboratory tests for compost suitability for application to the soil. The research revealed an increase in milk productivity, average daily gains of repair heifers, live weight at the first insemination, decrease in the number of retired repair heifers and cows from the main herd due to limb diseases. According to the results of the research, expert recommendations were given to the farm.
\end{abstract}

\section{Introduction}

The most rational method of manure processing from the point of view of the current situation in the farm is composting of pre-fermented manure, which minimizes the formation of secondary waste, and also prevents the occurrence of diseases of the limbs of animals.

Manure is a valuable organic fertilizer, it can contain a mixture of solid and liquid secretions of different animals, as well as its importance is great due to the content of a large amount of nutrients in it.

At the same time, manure has some negative aspects and is a potential source of the spread of infectious and invasive diseases. The greatest economic damage is caused by the content of weed seeds in manure. In the product manufacturing, large expenditures are directed to the control of weeds and harmful insects and their larvae.

Thus, on the one hand, the source manure is a valuable organic fertilizer, and on the other hand, its direct use without preliminary preparation poses a serious environmental hazard to environment, animals and people.

\footnotetext{
* Corresponding author: 79511917462@yandex.ru
} 
Various initial properties of the resulting manure led to the development of various technologies for preparing it for use. Thus, composting technologies are mainly used for litter manure [1-6].

When preparing clean manure (without litter), several methods are used. Special attention is paid to its characteristics and suitability for application to the soil. The most common methods of preparation are the following: composting of semi-liquid manure; homogenization of semi-liquid and liquid manure; separation of liquid manure into fractions in storage tanks; mechanical separation of liquid manure into fractions; separation of liquid manure with full biological treatment of the liquid fraction; separation of liquid manure with partial biological treatment of the liquid fraction.

We can observe the results of the application of various EM technologies on the examples of an increase in the average daily increments of young animals, as well as an increase in live weight during the first insemination and a decrease in the disposal of animals due to various diseases.

The introduction of EM technologies has many positive directions. When using such biopreparations, it is possible to achieve good wastewater purification, accelerated and rapid composting and processing of organic waste from livestock farms into valuable fermented fertilizers, eliminating unpleasant odors in cesspools and in industrial premises. It gives excellent results when introduced into animal husbandry, which is accompanied by an increase in milk yield, an increase in the fat content of milk and the mass fraction of protein, an increase in average daily gains [7-14].

\section{Materials and methods}

To determine the effect of the biopreparation "Tamir" on the efficiency of manure processing, two groups of animals with 50 heads each were analyzed. In one of the rooms, heifers were kept on a deep litter without the use of biopreparation, in another room with the use of biopreparation "Tamir". For the experiment, heifers from cows on the second lactation and older were selected. The live weight of the selected repair heifers for keeping without biopreparation (old technology) at birth was $31.75 \pm 0.33 \mathrm{~kg}$, and with the use of biopreparation (new technology) $32.85 \pm 0.54 \mathrm{~kg}$, that is, the difference in live weight when setting up for the experiment was only $1.1 \mathrm{~kg}$ (Table 1 ).

Table 1. Dynamics of the live weight of repair heifers.

\begin{tabular}{|c|c|c|}
\hline Indicator & $\begin{array}{c}\text { Without the use of } \\
\text { biopreparation }(\mathrm{n}=50)\end{array}$ & $\begin{array}{c}\text { With the use of } \\
\text { biopreparation }(\mathrm{n}=50)\end{array}$ \\
\hline Live weight: & $31.75 \pm 0.33$ & $32.85 \pm 0.54$ \\
\hline at birth, $\mathrm{kg}$ & $168.29 \pm 2.01$ & $183.00 \pm 3.01$ \\
\hline $\begin{array}{c}\text { at the age from birth to } 6 \\
\text { months, } \mathrm{kg}\end{array}$ & $321.62 \pm 5.02$ & $338.20 \pm 5.03$ \\
\hline at the age of one year, $\mathrm{kg}$ & $376.80 \pm 3.58$ & $395.25 \pm 4.33$ \\
\hline $\begin{array}{c}\text { at the first insemination, } \mathrm{kg} \\
\text { (age 15 months) }\end{array}$ & $450.20 \pm 5.35$ & $470.55 \pm 4.32$ \\
\hline at the age of 18 months, $\mathrm{kg}$ & $534.52 \pm 6.91$ & $545.87 \pm 3.21$ \\
\hline at the first calving, $\mathrm{kg}$ &
\end{tabular}

The live weight of heifers at the age of 6 months was $168.29 \mathrm{~kg}$ with the old technology and $183.00 \mathrm{~kg}$ with the new technology, which is already $14.71 \mathrm{~kg}$ more than with the old one. At the age of 12 months, the difference in live weight (338.20 vs. 321.62) of heifers was already $16.58 \mathrm{~kg}$, and at the first insemination $-376.80 \mathrm{~kg}$ and $395.25 \mathrm{~kg}$, the difference is $18.45 \mathrm{~kg}$, which is also in favor of the new technology. 
At the first calving, the live weight of animals with the old technology was $534.52 \mathrm{~kg}$, and with the new technology, the live weight increased by $11.35 \mathrm{~kg}$ and amounted to 545.87 $\mathrm{kg}$.

Thus, the live weight of animals at all age periods was in favor of the new technology of keeping with the use of biopreparation, since the animals were less ill and did not drop out of the herd.

The dairy productivity of cows by age groups was also analyzed. Studies have found that the milk yield for the first 100 days of lactation was in the range of 779.27-805.50 kg when kept without the use of biopreparation "Tamir", and with the use of biopreparation, the milk yield of animals varies between 868.26-898.25 kg. The difference in the content of FMF and PMF in milk with different keeping technologies is $0.2 \%$ and $0.06 \%$ in the first month, $0.06 \%$ and $0.15 \%$ in the second, $0.16 \%$ and $0.21 \%$ in the third. The difference in milk yield for 100 days of lactation is $140.69 \mathrm{~kg}$, which is also in favor of the new technology.

The results of milking cows after the first calving, which were kept under different conditions, are shown in Table 2.

Table 2. Milk productivity of first-calf cows for the first 100 days of lactation.

\begin{tabular}{|c|c|c|}
\hline Indicator & $\begin{array}{c}\text { Without the use of } \\
\text { biopreparation "Tamir" } \\
(\mathrm{n}=39)\end{array}$ & $\begin{array}{c}\text { With the use of } \\
\text { biopreparation "Tamir" } \\
(\mathrm{n}=45)\end{array}$ \\
\hline Milk yield for 100 days of lactation & $2528.23 \pm 77.82$ & $2668.92 \pm 92.69$ \\
\hline FMF, \% & $3.69 \pm 0.05$ & $3.89 \pm 0.03$ \\
\hline PMF, \% & $3.16 \pm 0.12$ & $3.27 \pm 0.03$ \\
\hline Milk fat amount, kg & $90.55 \pm 5.54$ & $105.11 \pm 2.43$ \\
\hline Milk protein amount, kg & $79.92 \pm 3.86$ & $87.62 \pm 3.15$ \\
\hline
\end{tabular}

Indicators of dairy productivity of cows in different age periods are shown in Table 3.

Table 3. Milk productivity of cows in different age periods.

\begin{tabular}{|c|c|c|c|c|}
\hline \multirow{2}{*}{ Indicator } & \multicolumn{2}{|c|}{$\begin{array}{c}\text { Milk productivity of first-calf cows with } \\
\text { different technologies }\end{array}$} & \multicolumn{2}{c|}{$\begin{array}{c}\text { Milk productivity of cows after the } \\
\text { third lactation and older with different } \\
\text { technologies }\end{array}$} \\
\cline { 2 - 5 } & old technology & new technology & old technology & new technology \\
\hline $\begin{array}{c}\text { Milk yield } \\
\text { for 100 } \\
\text { days of } \\
\text { lactation, } \\
\text { kg }\end{array}$ & $2528.23 \pm 77.82$ & $2668.92 \pm 92.69$ & $3102.40 \pm 149.13$ & $3472.75 \pm 195.11$ \\
\hline FMF, \% & $3.65 \pm 0.05$ & $3.93 \pm 0.03$ & $3.63 \pm 0.05$ & $3.58 \pm 0.07$ \\
\hline PMF, \% & $3.17 \pm 0.12$ & $3.27 \pm 0.03$ & $3.27 \pm 0.02$ & $3.28 \pm 0.02$ \\
\hline $\begin{array}{c}\text { Milk yield } \\
\text { for 305 } \\
\text { days of } \\
\text { lactation, } \\
\text { kg }\end{array}$ & $6778.51 \pm 303.70$ & $8242.83 \pm 84.95$ & $7732.71 \pm 480.79$ & $8898 \pm 800.92$ \\
\hline FMF, \% & $3.63 \pm 0.09$ & $3.66 \pm 0.03$ & $3.77 \pm 0.04$ & $3.78 \pm 0.07$ \\
\hline PMF, \% & $3.23 \pm 0.03$ & $3.28 \pm 0.02$ & $3.28 \pm 0.01$ & $3.29 \pm 0.01$ \\
\hline $\begin{array}{c}\text { MF } \\
\text { amount, kg }\end{array}$ & $245.39 \pm 10.48$ & $314.20 \pm 6.69$ & $293.20 \pm 18.45$ & $359.80 \pm 42.84$ \\
\hline $\begin{array}{c}\text { MP } \\
\text { amount, kg }\end{array}$ & $218.51 \pm 10.54$ & $281.65 \pm 5.49$ & $254.37 \pm 15.85$ & $310.05 \pm 33.16$ \\
\hline
\end{tabular}

The milk productivity of the first heifers for three months (the period of days in milk) with the new technology was $2668.23 \mathrm{~kg}$, which is $5.6 \%$ higher than with the old technology 
of maintenance. The indicators of the mass fraction of fat and protein also increased, with the new technology, the FMF indicator is $3.93 \%$, which is $0.28 \%$ higher with the content of cows in the old technology, the PMF indicator is $3.27 \%$, which is $0.1 \%$ higher than with the old technology.

The milk yield of first-calf cows for $4-5$ months increased by $376.45 \mathrm{~kg}$ and with the new technology it was $1815.55 \mathrm{~kg}$. The difference in the mass fraction of fat and protein is $0.1 \%$ and $0.02 \%$, respectively.

The milk yield of first-calf cows for 305 days of lactation was $6778.51 \mathrm{~kg}$ with the old technology and $8242.83 \mathrm{~kg}$ with the new technology of maintenance, which is $1464.32 \mathrm{~kg}$ more than with the old technology. Also, the amount of milk fat increased by $68.81 \mathrm{~kg}$, milk protein by $63.14 \mathrm{~kg}$, and amounted to $314.20 \mathrm{~kg}$ and $281.65 \mathrm{~kg}$, respectively, with the new technology.

The milk yield of cows on the third lactation and older, kept according to the new technology, also increased. During the period of distribution, the difference in milk yield is $370.35 \mathrm{~kg}$, the indicator of the mass fraction of fat decreased by $0.05 \%$, the indicator of the mass fraction of protein increased by $0.01 \%$.

Milk yield of cows on the third lactation and older for 4-5 months increased by 308.65 $\mathrm{kg}$, and was $1944.25 \mathrm{~kg}$. For 6-7 months during lactation, the difference in milk yield was $246.04 \mathrm{~kg}$, for 8 months $-165.6 \mathrm{~kg}$.

The milk yield of cows on the third lactation and older for 305 days of lactation was $7732.71 \mathrm{~kg}$ with the old technology, and $8898.0 \mathrm{~kg}$ with the new technology of maintenance, which is $1165.29 \mathrm{~kg}$ more. Accordingly, the amount of milk fat increased by $66.60 \mathrm{~kg}$, milk protein - by $55.68 \mathrm{~kg}$, and amounted to $359.80 \mathrm{~kg}$ and $310.05 \mathrm{~kg}$, respectively, with the new technology.

Additionally, the disposal of repair heifers from the herd associated with limb diseases before and after the use of the biopreparation was investigated. The results of the studies showed that in 2013-2014, that is, before the use of the biopreparation, heifers aged 10-12 months were eliminated from the herd in total amount of 12 heads (2013) or $1.4 \%$ and 13 heads (2014) or 1.4\%; aged from 12 to 18 months - only 9 heads (2013) or $1.1 \%$ and 12 heads (2014) or 1.3\%; aged 18 months and older - only 3 heads (2013) or $0.6 \%$ and 8 heads (2014) or $0.5 \%$ of the total amount of gender and age groups of animals (Table 4) [15-19].

Table 4. Indicators of the live weight of repair heifers by age periods and the number of culled animals due to limb disease.

\begin{tabular}{|c|c|c|c|c|c|c|}
\hline $\begin{array}{l}\text { Animal } \\
\text { group }\end{array}$ & $\begin{array}{l}\text { Availability } \\
\text { of repair } \\
\text { heifers at } \\
\text { the } \\
\text { beginning } \\
\text { of the year }\end{array}$ & $\begin{array}{l}\text { Dropped out } \\
\text { altogether due } \\
\text { to limb disease } \\
\text { of repair } \\
\text { heifers }\end{array}$ & $\begin{array}{l}\% \text { of } \\
\text { eliminat } \\
\text { ed from } \\
\text { the herd }\end{array}$ & $\begin{array}{l}\text { Average } \\
\text { daily } \\
\text { increase, } \\
\text { g }\end{array}$ & $\begin{array}{l}\text { Body } \\
\text { weight, } \\
\text { kg }\end{array}$ & $\begin{array}{l}\text { Live } \\
\text { weight at } \\
\text { the first } \\
\text { inseminatio } \\
\mathrm{n}, \mathrm{kg}\end{array}$ \\
\hline \multicolumn{7}{|c|}{ Before using the preparation } \\
\hline \multicolumn{7}{|c|}{2013} \\
\hline 10 months & 132 & 12 & 9.1 & 770 & 260 & \multirow[t]{4}{*}{382} \\
\hline 12 months & 360 & 9 & 2.5 & 738 & 305 & \\
\hline 18 months & 364 & 3 & 0.8 & 705 & 422 & \\
\hline Total & 856 & 24 & 2.8 & $\mathrm{X}$ & $\mathrm{X}$ & \\
\hline \multicolumn{7}{|c|}{2014} \\
\hline 10 months & 149 & 13 & 8.7 & 734 & 259 & \multirow[t]{4}{*}{381} \\
\hline 12 months & 343 & 12 & 3.5 & 672 & 281 & \\
\hline 18 months & 440 & 8 & 1.8 & 710 & 425 & \\
\hline Total & 932 & 33 & 3.5 & $\mathrm{X}$ & $\mathrm{X}$ & \\
\hline \multicolumn{7}{|c|}{ After using the preparation } \\
\hline & & & 018 & & & \\
\hline
\end{tabular}




\begin{tabular}{|c|c|c|c|c|c|c|}
\hline 10 months & 328 & 9 & 1.1 & 820 & 265 & \multirow[t]{4}{*}{395} \\
\hline 12 months & 489 & 7 & 0.8 & 785 & 306 & \\
\hline 18 months & 492 & 2 & 0.2 & 770 & 435 & \\
\hline Total & 1309 & 18 & 2.2 & $\mathrm{X}$ & $\mathrm{X}$ & \\
\hline \multicolumn{7}{|c|}{2019} \\
\hline 10 months & 334 & 7 & 2.7 & 815 & 269 & \multirow[t]{4}{*}{400} \\
\hline 12 months & 509 & 5 & 0.9 & 790 & 302 & \\
\hline 18 months & 503 & 2 & 0.4 & 764 & 435 & \\
\hline Total & 1346 & 14 & 1.1 & $\mathrm{X}$ & $\mathrm{X}$ & \\
\hline \multicolumn{7}{|c|}{2020} \\
\hline 10 months & 354 & 6 & 1.7 & 826 & 273 & \multirow[t]{4}{*}{403} \\
\hline 12 months & 548 & 4 & 0.7 & 798 & 313 & \\
\hline 18 months & 575 & 1 & 0.2 & 765 & 442 & \\
\hline Total & 1477 & 11 & 0.7 & $\mathrm{X}$ & $\mathrm{X}$ & \\
\hline
\end{tabular}

In addition, the indicators of the disposal of young animals from the main herd associated with limb diseases after using the biopreparation were studied. The research results showed that in 2018-2020, that is, after the use of the biopreparation, heifers aged 10-12-18 months dropped out of the herd in 2018: 9 heads $-1.1 \%$, 7 heads $-0.8 \%, 2$ heads $-0.2 \%$; in 2019 , aged 10-12-18 months: 7 heads $-2.7 \%, 5$ heads $-0.9 \%, 2$ heads $0.4 \%$; in $2020,10-12-18$ months and older: 6 heads $-1.7 \%, 4$ heads $-0.7 \%, 1$ head $-0.2 \%$ of the total number of gender and age groups of animals.

The analysis of the disposal of repair young animals due to limb diseases by year was also carried out. If 24 heads or $2.8 \%$ in 2013,33 heads or $3.5 \%$ in 2014 were eliminated from the herd before the use of the biopreparation in 2013-2014, and as a result of the use of the biopreparation in 2018-2020, the indicator value decreased to: 18 heads or 2.2\% in 2018, 14 heads or $1.1 \%$ in 2019,11 heads or $0.7 \%$ in 2020 .

In total, the percentage of retired repair young animals as a result of the use of the biopreparation decreased from $2.8-3.5 \%$ to $1.0-0.7 \%$, or almost three times.

Additionally, the indicators of the live weight of the repair young animals at the first insemination were studied. It can be seen that in 2013-2014, before the use of the biopreparation, the live weight of the repair young animals at the first insemination was 382$381 \mathrm{~kg}$, and in 2018-2020, after the use of the preparation, it was $395-403 \mathrm{~kg}$, which also indicates a positive effect of the preparation on their growth.

And finally, the indicators of the disposal of cows and first-calf cows from the herd for various reasons, including limb diseases before and after the use of the biopreparation, the results of which are presented in Table 5, were studied.

Table 5. Disposal of cows from the herd for reasons of disease before the use of the biopreparation.

\begin{tabular}{|c|c|c|c|c|c|c|c|c|}
\hline \multirow{3}{*}{$\begin{array}{l}\text { Group of } \\
\text { animals } \\
\text { (cows, } \\
\text { including } \\
\text { heifers) }\end{array}$} & \multirow{3}{*}{$\begin{array}{l}\text { Availability } \\
\text { of cows }\end{array}$} & \multirow{3}{*}{$\begin{array}{l}\text { Total } \\
\text { eliminated }\end{array}$} & \multicolumn{6}{|c|}{ Including } \\
\hline & & & \multirow[b]{2}{*}{$\begin{array}{l}\text { low } \\
\text { productivity }\end{array}$} & \multicolumn{4}{|c|}{ Diseases } & \multirow[b]{2}{*}{ other } \\
\hline & & & & $\begin{array}{l}\text { gynecological } \\
\text { and dryness }\end{array}$ & $\begin{array}{l}\text { of } \\
\text { udder }\end{array}$ & $\begin{array}{l}\text { of } \\
\text { limbs }\end{array}$ & $\begin{array}{l}\text { injuries, } \\
\text { accidents }\end{array}$ & \\
\hline \multicolumn{9}{|c|}{2013} \\
\hline Cows & 1520 & 436 & 143 & 73 & 114 & 49 & 10 & 47 \\
\hline$\%$ & 100.0 & 28.7 & 32.7 & 16.7 & 26.1 & 11.2 & 2.3 & 10.8 \\
\hline $\begin{array}{l}\text { Of them } \\
\text { first } \\
\text { heifers }\end{array}$ & 539 & 82 & 41 & 12 & 3 & 9 & 8 & 9 \\
\hline$\%$ & 100.0 & 15.2 & 50.0 & 14.6 & 3.7 & 11.3 & 9.8 & 11.3 \\
\hline \multicolumn{9}{|c|}{2014} \\
\hline Cows & 1596 & 429 & 149 & 53 & 86 & 44 & 12 & 85 \\
\hline$\%$ & 100.0 & 26.9 & 34.7 & 12.4 & 20.04 & 10.3 & 2.8 & 19.8 \\
\hline
\end{tabular}




\begin{tabular}{|l|c|c|c|c|c|c|c|c|}
\hline $\begin{array}{l}\text { Of them } \\
\text { first } \\
\text { heifers }\end{array}$ & 487 & 64 & 11 & 8 & 5 & 8 & 3 & 29 \\
\hline$\%$ & 100.0 & 13.1 & 17.2 & 12.5 & 7.8 & 12.5 & 4.7 & 45.3 \\
\hline
\end{tabular}

\section{Results and discussion}

According to the results of the conducted experiment, it should be noted that after the use of the biopreparation, the outflow of young animals due to limb disease from the main herd decreased by $0.6 \%(2.2 \%)$ in 2018 , compared to 2013 . $(2.8 \%)$; in 2019 , by $2.4 \%(0.7 \%)$ compared to 2014 . (3.5\%), and in 2020, the outflow of young animals due to limb diseases decreased to $0.7 \%$. The disposal of cows from the main herd due to limb diseases also decreased from $11.8 \%$ in 2018 to $6.7 \%$ in 2020 . Thus, we can safely say that the use of the biopreparation "Tamir" when keeping repair heifers on a deep litter favorably affected the health of animals and allowed to increase both meat and subsequently dairy productivity.

According to the results of the preparation use, the indicators of the disposal of cows and first-calf cows from the main herd for 2018-2020 were studied. (Table 6).

Table 6. Reasons for the disposal of the breeding stock from the main herd after using the preparation.

\begin{tabular}{|c|c|c|c|c|c|c|c|c|}
\hline \multirow{3}{*}{$\begin{array}{l}\text { Group of } \\
\text { animals } \\
\text { (cows, } \\
\text { including } \\
\text { heifers) }\end{array}$} & \multirow{3}{*}{$\begin{array}{l}\text { Availa } \\
\text { bility } \\
\text { of } \\
\text { cows }\end{array}$} & \multirow{3}{*}{$\begin{array}{l}\text { Total } \\
\text { elimin } \\
\text { ated }\end{array}$} & \multicolumn{6}{|c|}{ Including } \\
\hline & & & \multirow{2}{*}{$\begin{array}{l}\text { low } \\
\text { produc } \\
\text { tivity }\end{array}$} & \multicolumn{4}{|c|}{ Diseases } & \multirow{2}{*}{$\begin{array}{l}\text { othe } \\
\mathrm{r}\end{array}$} \\
\hline & & & & $\begin{array}{l}\text { gynecological } \\
\text { and dryness }\end{array}$ & $\begin{array}{l}\text { of } \\
\text { udder }\end{array}$ & of limbs & $\begin{array}{l}\text { injuries, } \\
\text { accidents }\end{array}$ & \\
\hline \multicolumn{9}{|c|}{2018} \\
\hline Cows & 1910 & 216 & 58 & 43 & 75 & 25 & 5 & 10 \\
\hline$\%$ & 100.0 & 11.3 & 26.9 & 19.9 & 34.7 & 11.8 & 2.3 & 4.6 \\
\hline $\begin{array}{l}\text { First-calf } \\
\text { heifers }\end{array}$ & 928 & 53 & 18 & 14 & 2 & 3 & 1 & 3 \\
\hline$\%$ & 100.0 & 5.7 & 33.9 & 26.41 & 3.8 & 5.7 & 1.9 & 5.7 \\
\hline \multicolumn{9}{|c|}{2019} \\
\hline Cows & 2010 & 260 & 70 & 44 & 96 & 15 & 10 & 25 \\
\hline$\%$ & 100.0 & 12.9 & 26.9 & 16.9 & 36.9 & 5.7 & 3.8 & 9.6 \\
\hline $\begin{array}{l}\text { First-calf } \\
\text { heifers }\end{array}$ & 654 & 56 & 8 & 11 & 14 & 4 & 2 & 17 \\
\hline$\%$ & 100.0 & 8.6 & 14.3 & 19.6 & 25.0 & 7.1 & 3.6 & 3.04 \\
\hline \multicolumn{9}{|c|}{2020} \\
\hline Cows & 2300 & 285 & 98 & 58 & 82 & 19 & 9 & 19 \\
\hline$\%$ & 100.0 & 12.3 & 32.3 & 20.4 & 28.8 & 6.7 & 3.2 & 6.7 \\
\hline $\begin{array}{l}\text { First-calf } \\
\text { heifers }\end{array}$ & 796 & 103 & 38 & 25 & 26 & 6 & 3 & 5 \\
\hline$\%$ & 100.0 & 12.9 & 36.9 & 24.3 & 25.2 & 5.8 & 2.9 & 4.9 \\
\hline
\end{tabular}

Research data showed that in 2018, a total of 216 cows were eliminated from the herd, which amounted to $11.3 \%$ of the total number of cows, in $2019-260(12.9 \%)$, in $2020-285$ $(12.3 \%)$ of the total number of cows, of which 53 heads $(5.7 \%)$ were eliminated in 2018,56 heads $(8.6 \%)$ in 2019,103 heads $(12.9 \%)$ in 2020.

The largest number of cows dropped out of the herd in 2018-2019 due to udder diseases in 2018 - 34.7\% (75 heads); in 2019, 36.9\% (96 heads); in 2020, the maximum rate of retirement due to low productivity is $32.3 \%$ (98 heads).

The results of the studies showed that the retirement of cows and first-calf heifers from the herd due to limb disease after using the preparation in 2018 was 25 heads or $11.8 \%$; in 2019 - 10 heads or $3.8 \%$; in 2020 - 19 heads or $6.7 \%$. 
It is worth noting that as a result of the use of the biopreparation, the number of retired cows, including first-calf heifers from the herd caused by limb diseases has decreased (Table 7).

Table 7. The number of cows diposed from the main herd due to limb diseases.

\begin{tabular}{|l|c|c|c|c|c|}
\hline \multirow{2}{*}{$\begin{array}{l}\text { Gender and age } \\
\text { group }\end{array}$} & \multicolumn{2}{|c|}{$\begin{array}{c}\text { Before the use of } \\
\text { biopreparation "Tamir" }\end{array}$} & \multicolumn{3}{c|}{ After the use of biopreparation } \\
\cline { 2 - 6 } & 2013 & 2014 & 2018 & 2019 & 2020 \\
\hline Cows & 49 & 44 & 25 & 15 & 19 \\
\hline$\%$ & 11.2 & 10.3 & 11.8 & 5.7 & 6.7 \\
\hline First-calf cows & 9 & 8 & 3 & 4 & 6 \\
\hline$\%$ & 11.3 & 12.5 & 5.7 & 7.1 & 5.8 \\
\hline
\end{tabular}

\section{Conclusions}

According to the research results, we can say that the use of the biopreparation "Tamir" for the processing of organic fertilizer had a positive effect. This is noticeable in such indicators as a decrease in the percentage of disposal of young animals and improvement of average daily gains over the growing periods and live weight; live weight at the first insemination; reduction in the disposal of young animals; disposal of cows, including first-calf heifers from the herd associated with limb diseases; increase in milk productivity indicators: milk yield, mass fraction of fat and protein [20-22].

To prevent limb diseases, increase the average daily increments of repair young animals, reduce the retirement from the main herd, increase the dairy productivity of cows, it is necessary to use the biopreparation "Tamir" in all sections where animals are kept with loosebox technology on a deep litter.

\section{References}

1. S.I. Evstafyev, Features of the cultivation of repair young cattle of black-and-white breed in the conditions of farms. In the collection: Scientific works of students of the Izhevsk SAA FSBEI HE Izhevsk SAA, 74-79 (Izhevsk, 2017)

2. M.R. Kudrin, O.A. Krasnova, V.A. Nikolaev, M.S. Perevozchikova, O.S. Fedorov, Journal Izvestia of the Gorsky State Agrarian University, 4 (55), 70-76 (2018)

3. D.I. Kurteev, Scientific works of students of the Izhevsk State Agricultural Academy $\mathbf{1}$ (10), 701-706 (2020)

4. L.P. Korobeynikova, E.A. Kardapoltseva, Scientific works of students of the Izhevsk State Agricultural Academy 1 (10), 696-701 (2020)

5. K.P. Nazarova, Scientific works of students of the Izhevsk State Agricultural Academy 3(4), 346-350 (2017)

6. K.P. Nazarova, K.S. Simakova, Scientific works of students of the Izhevsk State Agricultural Academy, 64-67 (2016)

7. M.S. Perevoshchikova, Scientific works of students of the Izhevsk State Agricultural Academy, 333-339 (2019)

8. Ya.L. Ponomareva, Scientific works of students of the Izhevsk State Agricultural Academy 3(4), 360-366 (2017)

9. K.S. Simakova, Scientific works of students of the Izhevsk State Agricultural Academy 3(4), 369-374 (2017) 
10. M.R. Kudrin, O.A. Krasnova, A.G. Koshchaev, O.V. Koshchaeva, M.B. Ulimbashev, N.V. Konik, S.V. Shabunin, Journal of Ecological Engineering 20(11), 58-66 (2019)

11. M.R. Kudrin, G.Y. Berezkina, A.L. Shklyaev, L.A. Shuvalova, I.A. Deryushev, IOP Conference Series: Earth and Environmental Science, 7, 315, 072034 (2019)

12. M.R. Kudrin, S.N. Izhboldina, K.L. Shklyaev, V.A. Nikolaev, N.V. Selezneva, IOP Conference Series: Earth and Environmental Science, 7, 315, 072028 (2019)

13. O.A. Krasnova, N.P. Kazantseva, M.R. Kudrin, E.V. Khardina, M.I. Vasilieva, M.G. Pushkaryov, N.A. Sannikova, International transaction journal of engineering, management and applied sciences and technologies, (11)14, 11A14G (2020)

14. G.Y. Berezkina, A.A. Korepanova, S.L. Vorobyova, E.M. Kislyakova, M.I. Vasilieva, Advances in animal and veterinary sciences, 8 (3), 23-26 (2020)

15. E. Klimova, M.R. Kudrin, T. Krylova, E. Maksimova, E.A. Mikheeva, Advances in animal and veterinary sciences, 8 (3), 56-62 (2020)

16. M.I. Vasilyeva, N.P. Kazantseva, Construction of floors at pig-breeding enterprises, Innovative technologies for the implementation of the program of scientific and technical development of agriculture: materials of the International Scientific and Practical Conference, 13-16 Feb. 2018 - Izhevsk, 2, 16-18 (2018)

17. O.A. Krasnova, N.P. Kazantseva, E.V. Khardina, M.I. Vasilieva, M.R. Kudrin, N.A. Sannikova, Ecology, Environment and Conservation, 26(4), 1587-1591 (2020)

18. T. Babintseva, E. Mikheeva, A. Shishkin, V. Yudin, E. Klimova, K. Shklyaev, Advances in animal and veterinary sciences, 8 (3), 11-17 (2020)

19. M.R. Kudrin, A.V. Kostin, A.L. Shklyaev, Microclimate and design of livestock enterprises, Izhevsk, (2020)

20. M.R. Kudrin, A.L. Shklyaev, O.A. Krasnova, Formation of a highly productive herd: Izhevsk, (2020)

21. A.G. Ivanov, S.P. Ignatiev, N.G. Kasimov, A.L. Shklyaev, M.V. Shklyaev, Rural machine operator 10, 30-31 (2020)

22. A.L. Shklyaev, M.R. Kudrin, K.L. Shklyaev, The mode of milk flow in circular cylindrical pipes of the milk pipeline and its influence on the quality of commercial products, In the collection: Scientific innovations in the development of agricultural industries. Proceedings of the International Scientific and Practical Conference, 3, 8487 (2020) 